\title{
From University to School—Experiences of Teaching Practice in Three Countries
}

\author{
Zhan $\operatorname{Dan}^{1} \&$ Xu Liu ${ }^{2}$ \\ ${ }^{1}$ Department of Education, King's College London, UK \\ ${ }^{2}$ Centre for Higher Education, Southern University of Science and Technology, China \\ Correspondence: Xu Liu, Centre for Higher Education, Southern University of Science and Technology, China. \\ E-mail: liux9@sustech.edu.cn
}

Received: January 14, 2021

Accepted: May 15, 2021

Online Published: July 22, 2021

doi:10.5539/ies.v14n8p1

URL: https://doi.org/10.5539/ies.v14n8p1

\begin{abstract}
Teaching practice plays an important role in preparing future teachers. More and more countries pay attention to teaching practice in teacher education and take measures to improve the system of teaching practice. This paper examines the characteristics of teaching practice through the perspective of comparative analysis, comparing the situations in China, the UK and the USA. The different characteristics are presented, particularly in the goal of teaching practice, the duration of the internship and the cooperation system among education administration departments, universities, and schools. Some suggestions are proposed to improve teaching practice generally based on experience of these three countries. As such, it provides insight into practice for policymakers and academics in the field of teacher education.
\end{abstract}

Keywords: teaching practice, teacher training, pre-service teacher education, China, UK, USA

\section{Introduction}

Teacher training plays an important role in preparing future teachers to educate the coming generations. Research attests to the important role of teacher education, showing that students' learning outcomes are greatly affected by the quality of teaching (Darling-Hammond, 2017; Wang, Odell, Klecka, Spalding \& Lin, 2010). Teachers who are better prepared for teaching are more confident and successful with their students than those who receive little or no training (Darling-Hammond, 2000). As noted by Kansanen (2003), countries worldwide acknowledge the importance of teacher education and practical experience. Many countries take measures which are suitable for their context to promote teacher training and there is an ongoing discussion of the role of the practical element, factors influencing it and the challenges involved, both for the institutions and the trainees.

In Canada, scholars have drawn attention to the impact of practical experience: Crocker and Dibbon (2008) conducted a survey to investigate pre-service teachers' attitudes towards their teaching practices; the results showed that it was considered to be the most valuable part of the teacher training process. The trainees also ranked the quality of supervision provided by university education staff lower than that provided by the schoolteachers in their teaching practices.

In Australia, teaching practice face many challenges despite ongoing reform of the programme (Ure, Gough, \& Newton, 2009). The difficulty concerned budgeting and forecasting of workloads for the hosting schools during teaching practices which resulted in a lack of financial and resource support. In the South African, teacher training had received the attention of policy makers. In 2000, the 'Norms and Standards for Educators' policy was published to guide teacher education and to promulgate that all teacher training should be in accordance with the regulations of this policy (Robinson, 2003). Finland puts a strong emphasis on practical experience and provides trainee teachers with suitable practical courses. Chennat (2014) noted that Finnish trainee teachers undertake three types of teaching practice: basic, advanced, and then final practice during their five-year training programme. However, Finnish teacher training also faces the challenge of how best to combine teaching practice and educational theory (Tryggvason, 2009).

In Asia, Japan considers teacher practice as essential in preparing teachers, and this is reflected in education policies designed to improve the quality of teaching practices. Japan required teaching practice is a necessary part of pre-service teacher education programme sponsored by the university. However, university tutors found it 
almost impossible to visit and observe their students on their teaching practices as these often took place during the university teaching term (Howe, 2008).

The situation is similar in China, where there has been a desire to develop teacher education. As early as 35 years ago, the Chinese Ministry of Education (MoE) recognized that teaching practice is essential in preparing qualified teachers in 1985. It stated that one of the key strategics to develop education would be the improvement of teacher training. Some scholars claim that the practical aspect of China's teacher training has many shortcomings, including pre-service teachers lacking a school for the teaching practice (Jiang, 2005; Huang, 2009), the duration of teaching practice being insufficient (Zhu \& Yang, 2001; Deng, 2006), and evaluations for teaching practice not always being objective (Wang, 2001). In 2011, the Teacher Education Curriculum Standards (MoE, 2011) stressed the importance of practical experience for trainee teachers; The document stated that practical orientation is one of the basic concepts of the teacher education curriculum. However, 'academically oriented teacher preparation, which prioritises subject matter knowledge for teaching', is still widely used in China (Liao \& Hu, 2017, p. 629).

The similar situation has happed in the USA where research has highlighted that teacher education is problematic (Alter \& Coggshall, 2009; Zeichner \& Bier, 2012; Guise et al., 2017). Moreover, teaching practice in the USA is subject to great variations across the country in the quality of mentoring and evaluating pre-service teachers (Valencia et al., 2009; Grossman, 2010). The United Kingdom also considers teacher practice is essential of teaching education. Cochran-Smith (2016) discusses teacher training and education policy in the UK and identifies one of the central aspects in current policies of teacher education is to pay a great attention on the practice.

Although many countries emphasize the significance of teaching practice, they have encountered difficulties involving financial support, policy, and institutional procedures. This study seeks to discover the similarities and differences between teaching practice in China, the USA and the UK. Following the introduction and the literature review, the third section will introduce the reason for using these three countries as cases. By using comparative analysis, some suggestions are proposed to improve the development of the teaching practice in the teacher training before closing with a conclusion.

\section{Literature Review}

As noted above, different terms are used to describe the part of the curriculum that is reserved for learning in professional practice, such as student teaching (Goodman, 1985; May \& Zimpher, 1986), field-based experiences (Zeichner, 2010), teaching practice (Mule, 2006) and internship (Darling-Hammond, 2000). Stones (1984) claims that, teaching practice is a process whereby the trainee teacher, through watching someone else teach, acquires teaching expertise and then attempts to do likewise. However, Van Velzen and Van der Klink (2014) point out that Stones' concepts of what was involved in the teaching practice were restricted and did not recognize its complexity. They suggested that the teaching practice had changed the focus from imitating the experienced teacher to pre-service teachers learning through doing the teaching and incorporating the advice of professionals. In recent years, some experts have argued the concept of 'clinical practice' during the internship, in which pre-service teachers not only use knowledge and skills but are also encouraged to evaluate and judge the achievements of both themselves and their students (Alter \& Coggshall, 2009; Kriewaldt \& Turnidge, 2013). Thus, in this study, teaching practice refers to the period when trainee teachers may master practical skills and participate in the creative processes of using resources, evaluating, and making judgments of achievements. Based on existed literature, the terms student teacher, pre-service teacher and trainee teacher, teacher training and teacher education, and teaching practice will be used interchangeably in this article.

There is general agreement that practical experience promotes the professional development of teachers as it offers pre-service teachers an opportunity to develop and consolidate a significant variety of knowledge and skills (Caires \& Almeida, 2005).

It enables student teachers to get practical experience (Marais \& Meier, 2004; Quick \& Siebörger, 2005), and allows the integration of theoretical aspects with practice which also considered as an initiation into the role of teacher (Maphosa, Shumba, \& Shumba, 2007; Evelein, Korthagen, \& Brekelmans, 2008). A teacher who only has theoretical knowledge is unqualified and to participate in the teaching experience in schools is essential to become a qualified teacher and (Wang, 2001; Jiang, 2005). In this regard, the various qualities and abilities of future teachers are formed in teaching practice as a direct result of contact with young people (Huang, 2009). Hence, the practical experience of and skills learnt from on-site training are crucial elements in equipping teachers (Deng, 2006). Its core goal is to develop good teaching skills and professional identity for future teachers (Wang \& Zhang, 2020).

Through engaging in teaching practice, the student teacher can gain a more comprehensive understanding of teachers' responsibilities. Hong (2010) states that all students teachers may start with idealistic expectations, only 
to find that things are different. Nghia and Tai (2017) argue that teaching practice provides student teachers with opportunities to learn more about the reality of this profession. To resolve this predicament, they have to not only change their unrealistic assumptions but also develop the skills to deal with any challenges they encounter. In terms of Liu and Liao (2019), the quality of professional development and its length which these student teachers perceived was positively associated with teacher' efficacy. Xiang (2004) adds that after experiencing teaching practice, student teachers have shown the capacity to adapt to reality in their understanding of the role of teachers and have begun to form the ability to actively mediate any conflicts between professional autonomy and the school system. As a result, this process eases the pressure of the transition from pre-service training to real teaching, thereby greatly reducing the discomfort of teachers new to teaching practice (Stokking, Leenders, De Jong, \& Van Tartwijk, 2003).

Some scholars argue that teaching practice play a particularly important function in developing student teachers' perceptions of their roles and responsibilities as qualified teachers (Mason, 1997; Harlin, Edwards, \& Briers, 2001; Poulou, 2007). As noted by Van Velzen, Bezzina, and Lorist (2009), student teachers who do not serve an internship may find it difficult to synthesize their subject matter expertise with their classroom management and pedagogical competencies.

Teaching practice can promote the socialization of pre-service teachers. Xiang (2004) explains socialization of teachers as a process in which individuals acquire professional knowledge and skills in education and then internalize professional norms, values and ethics, develop self-concepts, express role behavior patterns, and gradually become qualified for the professional role of being a teacher. Jiang (2005) notes that the environment of the practice school, its policies and culture, the guidance of instructors and interpersonal relationships all have an important impact on the socialization of pre-service teachers. Zhu (2006) suggests that these environmental forces determine trainees' attitude to the role, values and behavior of teachers through the influence of role expectations and norms because teachers are in a passive position in the process of socialization, following the existing social norms and expectations and performing established professional roles. Teaching practice is an important process in the socialization of pre-service teachers. Therefore, in terms of Liao and Maddamsetti (2019), it is important to create a supportive and inclusive professional community in which these student teachers can grow.

From the perspective of class management, student teachers learn the experience and method of the class teacher and read their work plan. Student teachers also need to conduct individual instruction based on student' unique characteristics. In addition, student teachers need to assist relevant personnel in organizing extracurricular activities such as knowledge contests and sports meetings (Wang \&Zhang, 2020). Through these activities, the student teacher learns how to manage the class and how to get along with students and colleagues. They can then form a whole reorganization and develop a well-informed structure of the teaching objectives (Li, 2018). In this case, the student teacher can develop their investigative skills and gain a better understanding of how to become an effective teacher.

Teaching practice is different from students' experience in teacher training colleges. There are four types of knowledge: knowing what, why, how and who (OECD, 2000). The theoretical curriculum of pre-service teacher education is designed to enable prospective teachers to acquire knowledge of 'what' and 'why' - theoretical knowledge such as the principles and laws of nature, human cognition and behavior, changes in society and educational research. However, in the process of the internship, pre-service teachers learn 'how' and 'who' through real education and teaching experience. McIntyre and Hagger (2008) stated that classroom teaching expertise cannot in principle be derived from theoretical or idealized views of teaching. If the prospective teacher relies only on the theoretical knowledge acquired in university, not only will they find it difficult to cope with the complexities and uncertainties of real teaching situations, but the prospective teacher's behavior and skills may have a significant negative impact on the pupils being taught. Therefore, the teaching practice is important to improve the professional development of pre-service teachers.

Teaching is carefully designed learning and it needs to be designed to achieve a certain goal (Murray, 1989; Ball \& Forzani, 2009). Teachers attempt to improve the probability of attaining specific intended goals by carefully arranging classroom content (Lampert, 2001; Lee, 2007). Because both the overall goal of teaching and the goal of each lesson are regulated, the content and form of classroom teaching requires teachers to design lessons purposefully. Mastering teaching ability requires professional learning and the teaching process needs to be carefully designed. In this case, teaching is a professional work and teachers need to be trained.

Teachers are responsible for evaluating the content from the learners' perspective and they need to consider problems from the perspective of students. They not only need to understand how students view the content of learning but also how students can learn the content better, and identifying the way that students think about 
knowledge is one part of teaching (Cohen, Raudenbush, \& Ball, 2003; Ball \& Forzani, 2007). Teaching decision making must base on professional requirements, for example, teachers cannot decide to disassociate with someone because they do not like them (Canh, 2014). Due to professional needs and teachers' ethics, teachers must maintain good communication with students and colleagues to work in harmony with them (Gao \& Benson, 2012; Kokkinos \& Stavropoulos, 2016).

Some scholars consider that teaching is intricate and that the complexity of teaching can be seen by acknowledging that communicating with different kinds of people is required (Lewis, 2007; Sleep, 2009). Teachers need to get along with colleagues, students and students' parents who have diverse personalities, thus the daily work of communicating is complex (Ashraf \& Zolfaghari, 2018). Lewis (2007) argued that each episode of instruction consists of many procedures, not all of which are visible to the casual observer. Sleep (2009) added that teachers shall make decisions about how to teach including how to utilize time in the classroom and choose their teaching materials in terms of the needs of students. Also, different students might react teaching content differently. Therefore, teachers need to adopt different teaching methods for different students. It is widely recognized that the result of teaching is affected by multiple factors including students' attitudes, teaching methods and the school's available resources. In this situation, the teacher needs to come up with many ideas to make the controllable factors more effective during the teaching.

\section{Methodology}

\subsection{Comparative as a Method}

The international comparisons are choosing in this study. The main reason is that an international comparison allows people to better understand what teaching practice involves in different countries. By comparing, individualities and commonalities of different countries are discovered to deepen understanding of and revealing the inherent essential features ( $\mathrm{Du}, 2017)$. The essence of comparison is to deepen the understanding of features from the comparison, so as to find rules and help researchers to draw scientific conclusions. Gu (2005) believes that in today's advocacy of globalization and multiculturalism, comparative research is one of the useful approaches to promoting exchanges between countries in educational concepts, systems and practices. Rao and $\mathrm{Wu}$ (2019) point out that comparison is suitable for helping educational policy makers and practitioners to understand the common problems they face and the differences between countries and local areas. This means that through comparison, people can understand the system and content of teaching practice in different parts of the world and explore the reasons why different countries make different decisions regarding the same issue.

Comparison can offer valuable lessons and references (Yan, 2016; Rao \& Wu, 2019). Alexander (2001) and Zheng (2005) suggested that national cultures influence educational policies and practices both locally and globally. Furthermore, comparative analysis is a good way to provide perspectives to understand how policies in various countries have developed (Broadfoot, 2002). Comparative analysis can influence educational decision-making and promote the improvement of teaching practice (Yang, 2015). By analysing the characteristics and challenges of the development of educational teaching practice in other countries, we can learn from their successes and failures.

\subsection{Three Case Countries}

In China, the curriculums for teaching practice always involve teaching observation, practice, and research. Guo (2015) conducted research on ten universities and found that although there are some differences in curriculum contents, teaching observation, practice and research is mandatory in every school. The content of practical curriculums can be divided into four aspects: teaching including preparation and feedback, class management and research. Wang and $\mathrm{Li}$ (2010) proposed that practical curriculum content with the intention to get school experience always includes teaching, class management and educational research. All three aspects can contribute to the development of pre-service teacher training.

Regarding the aspect of teaching work, pre-service teachers in China are responsible for analyzing textbooks, preparing lessons, writing lesson plans, supervised teaching, after-school tutoring, homework corrections, assessing students and giving feedback. In this way, they can learn teaching skills from observing experienced teachers and from participating in the teaching process. By being exposed to these practices in a genuine teaching atmosphere, pre-service teachers can get practical experience, develop their teaching skills, and learn more effective approaches to teaching (Smith \& Lev-Ari, 2005).

China and the United States have similar tracks in the development of the teaching practice programme. In 1922, the reform of the educational system in China was based on the experience of the United States (Ding, 2001) and, as a result, the teacher education systems of the two countries have many similarities. From the perspective of the development of teaching practice, the Chinese and American teaching practice programmes almost simultaneously 
underwent their budding, growing, and stable periods, entering a transformation period in the 1950s (Luo, 2009; $\mathrm{Wu}, 2015)$. Over nearly one hundred years of development, the teaching practice programmes in these two countries have adopted specific curriculum models. Moreover, the theory-application model derived from the experimental model of the United States is still the main model for today's Chinese teaching practice programmes. On this basis, the comparison of the teaching practice of the two countries is a natural observation and reflection on the growth and development of the same research object. It is thus noticeable that this comparison is comparable and appropriate.

Britain and the United States have accumulated years of experience in the reform of practical education in pre-service teacher education, which is worth learning from. Ji (2010), Kong (2012), and Li (2018) state that these two countries have similar, highly developed educational systems. Currently, in the UK, the implementation of teaching practice realizes the organic integration of educational theory and practice to a large extent, thanks to the establishment of mutual assistance and cooperative partnerships between universities and primary and secondary schools (Oates \& Bignell, 2019). In the USA, the teaching practice model of 'university and elementary school cooperation' aims to provide intern teachers with 'clinical' practice opportunities through the establishment of cooperative partnerships ( $\mathrm{Ji}, 2010)$ so that educational teaching practice can contribute to increasing pre-service teachers' practical teaching experience and effectively promote their professional development. $\mathrm{Wu}(2015)$ shows as an education powerhouse, the United States pays great attention to the development of teacher education and is at the forefront of global initiatives to reform teaching practice in pre-service teacher education.

As Li (2008) noted, using comparative analysis requires comparable entities. In the context of the UK, the USA and China, the three countries have some similarities which are the foundation for comparison. They have roughly the same teacher training curriculum structure -general courses, professional subject courses and educational courses with only slight differences in name (Xu \& Cui, 2008; Chen \& Gao, 2011; Li, 2018). The teaching practice content is similar which includes educational observation and educational internship (Ji, 2010; Hou, 2011). Therefore, choosing these three countries for research has the potential to achieve better insights for the development of teaching practice in pre-service teacher education.

This study focuses on the analysis of Chinese and English literature. Essays relevant to Chinese policies on teaching practice were screened. The research terms of particular interest were 'pre-service teacher education', 'teaching practice' and 'internship(s)'. This paper conducted the review in stages by reading abstracts and choosing relevant essays first; next, reading the full text of the chosen texts and selecting the pertinent information; finally, finding connected literature through the references. After reading the selected essays, the analysis was divided into different aspects in terms of the literature. It then reviewed the literature on this subject in the United States and the United Kingdom. These two countries are not only developed countries but also have accumulated years of experience in practical educational reforms. The paper searched for articles from the UK and the USA through the research terms, and references to UK or USA initial teacher education and teaching practice. By introducing the attitudes and measures of the United Kingdom and the United States towards teaching practice, this paper explores the similarities and differences between China and the United States or the United Kingdom on this topic.

\section{Teaching Practice in Three Counties}

\subsection{China}

Since the establishment of the People's Republic of China (PRC), the practical teaching of teacher education can be divided into three categories: construction, exploration, restoration and development (Chen \& He, 2020). The first development period of the Chinese educational practice curriculum was before the founding of the Republic of China in 1949. This can be seen in the ancient emphasis on teaching practice found as early as the Spring and Autumn Period (770BC-221BC). Confucius believed that learning is a process which consists of three parts including learning, thinking and action and he believed that the teaching practice as an action, is key to improve the learning and thinking (Liu, 2001).

In 1897, the Chinese government established the Nanyang Public School to train teachers in Shanghai (Shu, 1965). This school became the first school in Chinese history to run educational practical courses in teacher education. The Nanyang Public School modelled its programme on the system in Japan and established a practical teaching environment for pre-service teachers, where they could carry out one year of teaching practice within the school (Shu, 1965). From this time until the founding of the People's Republic in 1949, there were regular mandates from the Ministry of Education (MoE) promulgating practical training and internships as China's educational practice curriculum developed (Zhu, 1989; Liu \& Xie 2002; Bai, 2010).

The second stage of development of the teaching practice programme is the period from when the PRC was 
founded to the end of the Cultural Revolution. During this period, with the view of the Soviet model, China's practical curriculum changed considerably. In 1952, China stipulated in the Teaching Plan of Higher Teacher Schools that the four-year undergraduate teacher education programme must include a 12-week internship of the university year (Liu, 1993). Under the guidance of experts from the then Soviet Union, the Ministry of Education issued the "Temporary Teaching Plan for Teachers' Colleges" in 1954, which proposed that the teacher education plan consist of political theory, educational subjects, professional subjects, and educational practice ( $\mathrm{Li} \& \mathrm{Li}$, 2007). In addition, the document explained the purpose of educational practice was to enable students to understand the actual situation of school education through internships and practice, and to initially grasp the actual skills of school student education and teaching work. During the Cultural Revolution from 1966-1976, trainee teachers' practical course was in the stagnation period. With the emergence of the 10-year Cultural Revolution, both teaching practice and teacher education were destroyed. The reality was that teacher training colleges had stopped enrolling students, resulting in a serious lack of teachers. It can be concluded that in this period, the development of teacher education was destroyed as never before.

The third stage of development of the teaching practice programme is the developmental period from 1976 to present. The Third Plenary Session of the Eleventh Central Committee was held in late 1978. This meeting symbolizes the beginning of the Chinese economic reform. After that, the state emphasized the importance of teaching practice to pre-service teachers through the announcement of a number of policies. For example, the "Educational Teaching Program for All Subjects in Higher Teacher Schools" promulgated in 1978 stipulated that "educational practice is an important part of initial training for students. It can strengthen the integration of theory and practice and it thus must be implemented seriously" (Liu, 2001, p. 7).

In 1980, the MoE pointed out that teaching observations and internships are an important method for teachers' colleges to integrate theory with practice and train qualified teachers ( $\mathrm{Li}, 2006)$. Following this announcement, the education department began to resume practical component in teacher training courses. In the document of Decision on Educational System Reform, MoE (1985) stated that educational institutions should have more autonomy in running schools and could determine the location and time of practicums according to the school's culture and actual conditions. The activities of the teaching practice also increased. In 1995, the Ministry of Education stated that educational practice courses shall include educational observation, internship, and subject professional practice ( $\mathrm{Su}, 1996)$. From the beginning of the 21 st century, the state eager to find a new way that was most suitable for the development of teachers' practice courses (Fan, 2014). Trainee teachers are responsible for all teachers' tasks, including professional teaching, classroom management, and Interpersonal communication.

In China, the time allocated for a teaching practicum is around six to eight weeks (Shi et al., 2019; Zhang, 2008; Yang, 2009). It is generally arranged in the last period of undergraduate education (Wang, 2001; Deng, 2006). As teacher education is the basis of the construction of the whole society and the foundation to ensure the revival of social education, the state insists on having the leading role in teacher education policy in China (Huo, 2018). The Chinese government guides and manages teacher education and has a fundamental guiding role in the formulation of teacher education policies. However, Chen (2002) notes that China's special circumstances are not conducive to implementing a unified teaching practice policy across the entire nation. China's vast area and the diverse levels of educational development in the various provinces mean that it is not appropriate to adopt a singular approach to teaching practice. Instead, corresponding strategies and measures need to be adopted according to different situations. As one of the results, the Chinese government gave more autonomy to local administrative department which allowed teacher training colleges to determine some aspects of the teaching practice ( $\mathrm{Li}, 2003)$.

In addition, teacher training colleges are in charge of the programme of teaching practice in China (Zhu \& Yang, 1999; Chen, 2004). The state does not clearly stipulate that educational practice should be included in the daily work of primary and secondary schools (Shi et al., 2019). That means schools functioning as an internship location may simply passively accept university arrangements (Shi et al., 2019). However, Chen and He (2020) pointed out that new trends of practicum have appeared in which the university-school initiative where there is collaboration between universities and schools, and both contribute to the regulations of teaching practice. During the internship process, tutors pay more attention to the emotion of interpersonal communication, and pre-service teachers and tutors establish good relationships (Chang, 2007).

\subsection{The UK}

The UK was one of the first countries in the world to include teaching practice as part of teacher training. It has been committed to exploring effective strategies for integrating theory and practice in pre-service teacher education for decades (Ji, 2010; Hou, 2011). In the late 1980s, the British education authorities extended the duration of teaching practice and arranged for it to take place in each academic year of study. The teaching practice 
now is spread out over the three years of training, with most of it in the last year (Hou, 2011; Xin, 2011). There is an argument that the intensity of educational internship training in the UK is greater than in many countries (Xiao, 2006; Lan, 2011). For example, the pre-service teachers studying at the University of Edinburgh spent 32 weeks on teaching practice (Department for Education, 2020). Pre-service teachers are required to work the same as qualified teachers during their internship; they attend their school for eight hours a day, participate in school life and observe the school's experienced teachers in class (Department for Education, 2020). Thus, teaching practice in the UK is relatively long in terms of duration, and its form covers the stage changes and continuous growth of pre-service teachers. As a result, pre-service teachers can learn about the school running range from the beginning of enrollment and gradually deepen their understanding of the role of teachers.

In 1992, The New Requirements for Initial Teacher Training mandated a statutory requirement for teacher training institutions to build partnerships with schools, and jointly participate in arranging periods of teaching practice (Department for Education, 1992; Magni, 2019). This policy had shifted of teaching practice from entirely university-led to university and school cooperated (Furlong, Barton, Miles, Whiting, \& Whitty, 2000). The policy of educational teaching practice in the UK then has been a cooperative model between university and school (McNamara, Murray, \& Jones, 2014). Now, educational teaching practice in the UK is jointly undertaken by higher education institutions, local education authorities and internship schools. There is generally a partnership steering group composed of tripartite representatives who are responsible for formulating plans and specific programmes for educational teaching practice (Kong, 2009; Zhou, 2011; Fan, 2014). In addition, the local education authority is responsible for supervising the development of teacher education teaching practices and evaluating trainee teachers' practical abilities. Each institution performs its own duties, contributing to comprehensively guarantee the implementation of pre-service teacher education teaching practices in the UK.

In September 2012, the British Department for Education promulgated and implemented the new Teacher's Standards, which not only stipulated the overall requirements for educational teaching practice, but also included the school running key indicators. In terms of the document, pre-service teachers in the UK participate in the evaluation of educational teaching practice (Liu, 2014). The final evaluation of intern students is done by the instructors and intern students together and the students' self-evaluation is a basis for the instructor to make judgments and suggestions (Xin, 2011). The evaluation aspect in British teaching practice emphasizes objectivity, and the third-party educational institutions of the local education department will also evaluate the performance and ability of trainee teachers. It focuses on formative evaluation because of the dispersed nature of the teaching practice (Hou, 2011; Fan, 2014). This also means that the internship evaluation is not completed all at once (Kong, 2009) but is spread across all stages of the teaching practice. At the end of each semester, the tutor will evaluate the performance of pre-service teachers, providing timely feedback to help them continuously improve their teaching practice. Thus, to ensure the accuracy and detail of the evaluation results, instructors are required to always pay attention to collecting the evaluation data of intern students in the daily guidance process.

\subsection{The USA}

Before 1970, the teaching practice in the USA was arranged in the final stage of teacher education (Xiao, 2006). This practice was then gradually changed to both extend the total period of teaching practice and widen its distribution over the whole of the training curriculum. Teaching practice in the United States is divided into two stages. The first stage consists of simulated and in-school practice and lasts about 300 hours. This lays the foundation for cultivating the independent working ability of pre-service teachers. The second stage is the intensive internship before graduation. Pre-service teachers independently undertake the work of teaching, managing a class and participating in school activities, usually for a period of 15 to 24 weeks. The performance of pre-service teachers is determined by many factors (Kong, 2009). In the United States, formative evaluation is as important as summative evaluation; during the teaching practice, after discussions with the intern teacher, the instructor fills out the evaluation form based on their observations (Feng \& Lv, 2016). The final score of the intern is the sum of the two results of the mid-term evaluation and the final evaluation (Gong, 2011).

In the USA, universities have established macro and micro goals for teaching practice (Zuo, 2018). The macro goal is to tell the interns what they are going to become at the end of the programme, while the micro goals let them know what they are expected to achieve at each stage. It has clear requirements for choosing tutors and the selection criteria regarding instructors' teaching experience and professional qualifications (Gao, 2010; $\mathrm{Wu}$, 2015). Tutors in universities need to be familiar with school teaching and have rich practical experience ( $\mathrm{Li}, 2010)$. The internship tutors in schools are required to have three years of successful full-time teaching experience and during the teaching practice of teacher education; two mentors would jointly manage and plan the pre-service teachers' internship (Wu, 2015). The university instructors would observe and evaluate interns with cooperating teachers at regular intervals and provide feedback on the teaching practice to the pre-service teachers (Liang, 
2010).

There is also a cooperative relationship between universities and schools. Once a cooperative relationship is arranged, a formal agreement is signed between the teacher training institution, the school and the pre-service teachers which set out the terms of the relationship. The agreement clarifies the responsibilities and authorities of three parties, which ensure that the cooperation can continue even if the individuals in the institutions involved change (Liang, 2010). The evaluation of educational teaching practice involves the participation of university instructors, school cooperating teachers and interns. Interns who are not satisfied with the results can appeal to the school's educational internship department. This can enhance the objectivity of the teaching practice evaluation (Gong, 2011).

\section{Conclusion}

Through the comparison of the three countries, this article has discovered different strategies for implementing teaching practice for pre-service teachers. Assessing these experiences, some suggestions to improve the development of pre-service teacher education are put forward. This would provide insight into practice for policymakers and academics in the field of pre-service teacher education.

First, the goals of the teaching practice need to be specific. The internship goal plays a determining guiding role in the entire internship process since it stipulates the training standards as well as the evaluation indicators ( $\mathrm{Li}, 2018)$. The purpose of the teaching practice is to enable pre-service teachers to translate what they have learnt as theory and knowledge into practice, thus enabling them to teach independently ( $\mathrm{Ji}, 2010)$. If the setting of this goal is relatively general with no specific requirements, this results in the intern not being able to work toward the goal in a planned and methodical manner. In terms of the experiences of the United Kingdom and the United States, specific educational goals and detailed regulations are provided: the internship goals are clear and itemized so that pre-service teachers can act in an effective way. For example, it can stipulate that interns should cultivate class management and teaching evaluation capabilities. At the same time, these small goals can also be deployed to each specific teaching procedure so as to make the goals operable.

Second, the duration of the internship should be of an appropriate length. The American Association of Colleges for Teacher Education (2010) recommends that the educational internship should last for a minimum of one full semester (450 hours). It shall also pay attention to the timing of the teaching practice in the teacher training. As pointed out by Wang and Ren (2002) and Liu et al. (2016), it would be beneficial to distribute educational teaching practice across each semester of pre-service teacher education rather than only arranging it at the end of the teacher training, such as it is in China. Students would then be able to make a connection between theory and practice via their multiple experiences of internship (Manzar-Abbas \& Lu, 2013).

Third, it is important that education administration departments, universities, and schools establish a cooperative system to jointly manage and guide teaching practice. If teacher training universities position themselves as the trainers of qualified teachers, while schools limit their own functions to developing excellent students, this can often lead to a lack of communication between them (Ji, 2010). Without schools providing the internship place, it is difficult to train excellent teachers. Also, the establishment of a stable educational practice base can promote the continuous professional development of pre-service teachers. It is important to establish a cooperative relationship between teacher training institutions and schools to improve educational teaching practice. Therefore, it is recommended that universities, schools, and local governments reach consensus on cooperation in terms of teaching practice for pre-service teachers. In addition, it is valuable to instigate an effective evaluation system of teaching practice in pre-service teacher education. While the final performance is obviously an important indicator of the trainee teacher's progress, it is important to pay attention throughout the process of the internship.

\section{Acknowledgements}

This publication was supported by the Funding of Philosophy and Social Sciences of Guangdong (GD20CJY09), Funding of Guangdong Education Science "13th Five-Year Plan" (2020GXJK372) and Funding of Educational Science of Shenzhen (YBFZ20037).

\section{References}

Alexander, R. J. (2001). Border crossings: Towards a comparative pedagogy. Comparative Education, 37(4), 507-523. https://doi.org/10.1080/03050060120091292

Alter, J., \& Coggshall, J. G. (2009). Teaching as a Clinical Practice Profession: Implications for Teacher Preparation and State Policy. Issue Brief. National Comprehensive Center for Teacher Quality.

American Association of Colleges for Teacher Education. (2010). The Clinical Preparation of Teachers: A Policy 
Brief.

Broadfoot, P. (2002) Editorial: Educational policy in comparative perspective. Comparative Education, 38(2), 133-135. https://doi.org/10.1080/03050060220140539

Caires, S., \& Almeida, L. S. (2005). Teaching practice in Initial Teacher Education: its impact on trainee teachers' professional skills and development. Journal of Education for Teaching, 31(2), 111-120. https://doi.org/10.1080/03050060220140539

Chang, Y. L. (2007). Comparison of the Development of Educational Practice of Teacher University Students in China and America. Henan University.

Chen, S. J., \& Gao, J. X. (2011). Comparison of Pre-service Teacher Education Curriculum between China and America and Its Enlightenment to my country. Cultural and Educational Materials, 27, 97-99.

Chennat, S. (2014). Internship in pre-service teacher education programme: A global perspective. Australian Journal of Teacher Education, 15(1).

Cochran-Smith, M. (2016). Foreword, in: Teacher Education Group. Teacher Education in Times of Change.

Cohen, D. K., Raudenbush, S. W., \& Ball, D. L. (2003). Resources, instruction, and research. Educational evaluation and policy analysis, 25(2), 119-142. https://doi.org/10.3102/01623737025002119

Crocker, R. K., Dibbon, D. C., \& Raham, H. (2008). Teacher education in Canada. Kelowna, BC: Society for the Advancement of Excellence in Education.

Darling-Hammond, L. (2000). How teacher education matters. Journal of Teacher Education, 51(3), $166-173$. https://doi.org/10.1177/0022487100051003002

Darling-Hammond, L. (2007). Building a system for powerful teaching and learning. Building a 21st century US education system, 65-74.

Darling-Hammond, L. (2017). Teacher education around the world: What can we learn from international practice? European Journal of Teacher Education, 40(3), 291-309. https://doi.org/10.1080/02619768.2017.1315399

Darling-Hammond, L., \& Ducommun, C. E. (2011). Transforming Teacher Education. In Summit on Transformative Change in the Preparation of Teachers, California State University Summit.

Deng, L. M. (2006). Problems and Countermeasures in Educational Practice in Teacher Universities. Journal of Hubei Teacher University (Philosophy and Social Sciences Edition), 5, 130-134.

Department for Education. (1992). The New Requirements for Initial Teacher Training (Circular 9/1992), London.

Department for Education. (2020). Initial teacher training (ITT): Criteria and supporting advice. Retrieved from https:/www.gov.uk/government/publications/initial-teacher-training-criteria/initial-teacher-training-itt-criter ia-and-supporting-advice\#: :text $=\mathrm{a} \% 20$ four-year $\% 20$ undergraduate $\% 20$ programme,- $\% 20120 \% 20 \mathrm{days} \% 20$ (24\%20weeks

Ding, B. P. (2001). On the Reform and Innovation of Teacher Education in the United States-Teacher Professional Development School and Its Enlightenment to Us. Journal of Capital Teacher University (Social Science Edition), 2, 93-99.

Du, W. (2017). A Comparative Study on the Cultivation of Education Masters in China and America. Yunnan University.

Evelein, F., Korthagen, F., \& Brekelmans, M. (2008). Fulfilment of the basic psychological needs of trainee teachers during their first teaching experiences. Teaching and Teacher Education, 24(5), 1137-1148. https://doi.org/10.1016/j.tate.2007.09.001

Fan, Y. Y. (2014). A Comparative Study of Pre-service Teacher Education Practice Courses in China and Britain. Minnan Teacher University.

Feng, Q., \& Lv, L. J. (2016). American University Education Practice Program: Ideas, Models and Implications. Contemporary Education and Culture, 2, 99-105.

Furlong, J., Barton, L., Miles, S., Whiting, C., \& Whitty, G. (2000). Teacher Education in Transition: Re-forming Professionalism? Buckingham: Open University Press.

Gao, M. Y. (2010). Research on Educational Practice of American Teachers' Pre-service Education. Liaoning 
Teacher University.

Gong, D. M. (2011). The Experience and Enlightenment of American Educational Practice. Foreign elementary and secondary education, 3, 40-43, 49.

Goodman, J. (1985). What students learn from early field experiences: A case study and critical analysis. Journal of Teacher Education, 36(6), 42-48. https://doi.org/10.1177/002248718503600607

Grossman, P. (2010). Learning to practice: The design of clinical experience in teacher preparation. Policy Brief of the Partnership for Teacher Quality. Washington, D.C.: American Association of Colleges for Teacher Education.

Gu, M. Y. (2005) International Understanding and Comparative Education. Comparative Education Research, 12, $1-3,51$.

Guise, M., Thiessen, K., Robbins, A., Habib, M., Stauch, N., \& Hoellwarth, C. (2017). The evolution of clinical practice: Moving from traditional student teaching to co-teaching. In Handbook of research on teacher education and professional development (1-33). IGI Global. https://doi.org/10.4018/978-1-5225-1067-3.ch001

Guo, Y. (2015). Research on the Setting of Educational Practice Courses for Undergraduate Primary Education Majors (Master's thesis, Central University for Nationalities).

Harlin, J., Edwards, C., \& Briers, G. (2001). A comparison of trainee teachers'perceptions of important elements of the students' teaching experience before and after completing an 11-week field experience. In 28th Annual National Agricultural Education Research Conference.

Hong, J. Y. (2010). Pre-service and beginning teachers' professional identity and its relation to dropping out of the profession. Teaching and Teacher Education, 26(8), 1530-1543. https://doi.org/10.1016/j.tate.2010.06.003

Hou, D. J. (2011). Research on Educational Practice Curriculum in Pre-service Teacher Training in Britain. Southwest University.

Howe, E. R. (2008). Teacher induction across the Pacific: A comparative study of Canada and Japan. Journal of Education for Teaching, 34(4), 333-346. https://doi.org/10.1080/02607470802401503

Huang, F. F. (2009). The Characteristics and Realistic Enlightenment of British Educational Practice. Journal of Guizhou Educational Institute, 10, 27-32.

Ji, B. X. (2010). A Comparative Study of Pre-service Teacher Education Practice in Britain and America. Shanghai Teacher University.

Jiang, J. F. (2005). Practice and Thinking on the Construction of Educational Practice Base in Teacher Universities. China Higher Education Research, 5, 64-65.

Kansanen, P. (2003). Teacher education in Finland: Current models and new developments. Institutional approaches to teacher education within higher education in Europe: Current models and new developments, $85-108$.

Kong, F. C. (2012). Comparison of Teacher Education Curriculum Standards between China and Britain and Its Enlightenment. Chinese Journal of Education, 9, 67-70.

Kong, Y. (2009). Comparison and Enlightenment of the Characteristics of Teacher Education Practice in the United States and Britain. Journal of Liaoning Educational Administration Institute, 26(7), 56-58.

Kriewaldt, J., \& Turnidge, D. (2013). Conceptualising an approach to clinical reasoning in the education profession. Australian Journal of Teacher Education, 38(6), 103-115. https://doi.org/10.14221/ajte.2013v38n6.9

Lan, H. M. (2011). Comparison and Enlightenment of Practical Curriculum of Pre-service Teacher Education in China and Foreign Countries. Journal of Inner Mongolia Teacher University (Education Science Edition), 24(10), 84-86.

Li, C. (2010). A Comparative Study and Enlightenment of Educational Practice in Higher Teacher Education between China and America. Journal of Changchun University of Technology (Higher Education Research Edition), 31(4), 143-144.

Li, L. (2018). A Comparative Study of Pre-service Teacher Education Practice Courses in China and Britain. Henan Teacher University. 
Li, Z. F. (2008). Asking our situation: a contemporary analysis of comparability. Journal of Guangxi University (Philosophy and Social Sciences Edition), 1, 92-96.

Liang, L. (2010). An Analysis of the Practice of Cooperation between American Universities and School Partners. Southwest University.

Liao, W., \& Maddamsetti, J. (2019). Transnationality and Teacher Educator Identity Development: A Collaborative Autoethnographic Study. Action in Teacher Education, 41(4), 287-306. https://doi.org/10.1080/01626620.2019.1604275

Liao, W., \& Hu, S. (2017). Chinese teachers' perceptions of academically oriented teacher preparation. Journal of Education for Teaching, 43(5), 628-633. https://doi.org/10.1080/02607476.2017.1355084

Liu, H. X. (2014). Educational practice: British experience and inspiration (Master's thesis, Sichuan Teacher University).

Liu, H., Liu, C., Chang, F., \& Loyalka, P. (2016). Implementation of teacher training in China and its policy implications. China \& World Economy, 24(3), 86-104. https://doi.org/10.1111/cwe.12160

Liu, Y., \& Liao, W. (2019). Professional development and teacher efficacy: Evidence from the 2013 TALIS. School Effectiveness and School Improvement, 30(4), 487-509. https://doi.org/10.1080/09243453.2019.1612454

Luo, Z. (2009). A Comparative Study of Teacher Education Practice Courses in China and America. East China Teacher University.

Lv, L. J., \& Zheng, X. Y. (2008). The performance and analysis of the intern teacher's "reality shock". Foreign Education Research, 9, 9-13.

Magni, F. (2019). Initial Teacher Education Policies: A Comparison between Italy and the UK. Recent Trends and Future Prospects. Teacher Education for the 21st Century, 127. https://doi.org/10.2307/j.ctvpb3xhh.12

Manzar-Abbas, S. S., \& Lu, L. (2013). Keeping the teaching practice of Chinese preservice teacher education in world's perspective. International Journal of Academic Research in Business and Social Sciences, 3(4), 172-186.

Maphosa, C., Shumba, J., \& Shumba, A. (2007). Mentorship for students on teaching practice in Zimbabwe: Are trainee teachers getting a raw deal? South African Journal of Higher Education, 21(2), 296-307. https://doi.org/10.4314/sajhe.v21i2.25637

Marais, P., \& Meier, C. (2004). Hear our voices: Trainee teachers' experiences during practical teaching. Africa Education Review, 1(2), 220-233. https://doi.org/10.1080/18146620408566281

Mason, T. C. (1997). Urban field experiences and prospective teachers' attitudes toward inner-city schools. Teacher Education Quarterly, 29-40.

May, W. T., \& Zimpher, N. L. (1986). An Examination of Three Theoretical Perspectives on Supervision: Perceptions of Preservice Field Supervision. Journal of Curriculum and Supervision, 1(2), 83-99.

McNamara, O., Murray, J., \& Jones, M. (Eds.). (2014). Workplace Learning in Teacher Education: International Practice and Policy. Dordrecht: Springer. https://doi.org/10.1007/978-94-007-7826-9

MoE. (1985). Decision on Educational System Reform. Beijing.

MoE. (2011). Teacher Education Curriculum Standard. Beijing.

Mule, L. (2006). Preservice teachers' inquiry in a professional development school context: Implications for the teaching practice. Teaching and Teacher Education, 22, 205-218. https://doi.org/10.1016/j.tate.2005.09.011

Nghia, T. L. H., \& Tai, H. N. (2017). Preservice Teachers' Identity Development during the Teaching Internship. Australian Journal of Teacher Education, 42(8), 1-15. https://doi.org/10.14221/ajte.2017v42n8.1

Oates, C., \& Bignell, C. (2019). School and university in partnership: A shared enquiry into teachers' collaborative practices. Professional Development in Education, 1-15. https://doi.org/10.1080/19415257.2019.1689520

Organisation for Economic Co-operation and Development. (2000). Knowledge management in the learning society. Paris: OECD.

Poulou, M. (2007). Student-teachers' concerns about teaching practice. European Journal of Teacher Education, 30(1), 91-110. https://doi.org/10.1080/02619760600944993 
Quick, G., \& Siebörger, R. (2005). What matters in practice teaching? The perceptions of schools and students. South African Journal of Education, 25(1), 1-4.

Rao, C. M., \& Wu, Z. J. (2019). Country Studies in Comparative Education: Value Reaffirmation and Direction Exploration. Foreign Education Research, 12, 3-19.

Robinson, M. (2003). Teacher education policy in South Africa: The voice of teacher educators. Journal of Education for teaching, 29(1), 19-34. https://doi.org/10.1080/0260747022000057954

Smith, K., \& Lev-Ari, L. (2005). The place of the teaching practice in pre-service teacher education: The voice of the students. Asia-Pacific Journal of Teacher Education, 33(3), 289-302. https://doi.org/10.1080/13598660500286333

Stokking, K., Leenders, F., De Jong, J., \& Van Tartwijk, J. (2003). From student to teacher: Reducing practice shock and early dropout in the teaching profession. European journal of teacher education, 26(3), 329-350. https://doi.org/10.1080/0261976032000128175

Stones, E. (1984). Supervision in teacher education: A counselling and pedagogical approach. London: Methuen.

Tryggvason, M. T. (2009). Why is Finnish teacher education successful? Some goals Finnish teacher educators have for their teaching. European journal of teacher education, 32(4), 369-382. https://doi.org/10.1080/02619760903242491

Ure, C., Gough, A., \& Newton, R. (2009). Teaching practice Partnerships: Exploring Models of Teaching practice Organization in Teacher Education for a Standards-Based Profession. Strawberry Hills, Australia: Australian Learning and Teaching Council.

Valencia, S. W., Martin, S. D., Place, N. A., \& Grossman, P. (2009). Complex interactions in student teaching: Lost opportunities for learning. Journal of Teacher Education, 60(3), 304-322. https://doi.org/10.1177/0022487109336543

Van Velzen, C. P., \& Van der Klink, M. (2014). Developing teaching practice in the Netherlands: new concepts, new roles, new challenges. In Practical knowledge in teacher education Approaches to teacher practice programmes (pp. 180-194). Routledge.

Van Velzen, C., Bezzina, C., \& Lorist, P. (2009). Partnerships between schools and teacher education institutes. In Becoming a teacher educator (pp. 59-73). Springer, Dordrecht. https://doi.org/10.1007/978-1-4020-8874-2_5

Veenman, S. (1984). Perceived problems of beginning teachers. Review of educational research, 54(2), 143-178. https://doi.org/10.3102/00346543054002143

Wang, H. F., \& Zhang, Z. Q. (2020). Practice guidance system for normal university students-An empirical study on the effect of internship efficacy. Journal of Teacher Education, 7(4), 58-64.

Wang, H. X., \& Li, X. Y. (2010). A Comparative Study of Educational Practice Modes in Higher Teacher Colleges across the Straits. Higher Education of Science, 2, 69-74, 79.

Wang, J., Odell, S. J., Klecka, C. L., Spalding, E., \& Lin, E. (2010). Understanding teacher education reform. Journal of Teacher Education, 61(5), 395-402. https://doi.org/10.1177/0022487110384219

Wang, Q. \& Ren, Q. (2002). New model of teaching teaching practice in the new century. Huaibei Coal Teacher Institute Journal, 23, 14-18.

Wang, W. J. (2001). Rational thinking on the educational practice of higher teacher education in my country. Research on higher teacher education, 5, 65-69.

Wu, J. Y. (2015). A Comparative Study of Pre-service Teacher Education Practice in China and America. Hebei University.

Xiang, Y. G. (2004). On the current professional socialization of teachers at home and abroad. Foreign elementary and middle school education, 6, 13-19.

Xiao, M. L. (2006). An Analysis of the Characteristics of Foreign Teacher Education Practice. World Education Information, 4, 60-61, 64.

Xin, Y. H. (2011). Partner School-Practical Model and Enlightenment of British Pre-service Teacher Education. Hebei Teacher University. 
Xu, M., Cui, H., \& Li, J. (2008). Comparative Study of Educational Practice Modes in China and Foreign Countries. Foreign elementary and secondary education, 12, 25-30.

Yan, Y. (2016). Thoughts on the Value Orientation of Comparative Education. Academic Weekly, 10, 202-203.

Yang, D. H. (2009). The problems and countermeasures in teaching practice of trainee teachers. Journal of Higher Correspondence Education (Philosophy and Social Sciences Edition), 6, 69-70, 73.

Yang, M. Q. (2015). Beyond Tradition: Towards Critical and Localized Comparative Education. Journal of East China Teacher University (Education Science Edition), 33(4), 23-29.

Yu, X. H. (2008). The Development Process and Research Status of Educational Practice in my Country. Modern Educational Science, 1, 124-128.

Zeichner, K. (2010). Rethinking the connections between campus courses and field experiences in college- and university-based teacher education. Journal of Teacher Education, 6, 1-2, 89-99. https://doi.org/10.1177/0022487109347671

Zeichner, K., \& Bier, M. (2012). The turn toward practice and clinical experience in US teacher education. Beiträge zur Lehrerbildung, 30(2), 153-170.

Zhang, Y. C. (2006). Research on Educational Practice in Teacher Universities. Educational Theory and Practice, $16,16-17$.

Zhang, Y. Y. (2008). Thoughts on the Reform of Teacher Education Practice Courses in my country, Courses. Teaching materials and Teaching methods, 11, 84-87, 91.

Zheng, J. Z. (2005). Educational Culture. Beijing People's Education Press.

Zhou, Y. (2011). Study on the "School-based" Educational Practice Model in the UK. Sichuan Teacher University.

Zhu, P. Y. (2006). Research on Continuing Socialization of New Teachers (Master's degree thesis, Nanjing Teacher University).

Zhu, Y. X., \& Yang, S. B. (2001). Problems and Countermeasures in the Guidance of Educational Practice. Journal of Yangzhou University (Higher Education Research Edition), 1, 47-50.

Zuo, T. T. (2018). A Comparative Study of Teaching Practice of Foreign Language Teachers in China and America. Huazhong Teacher University.

\section{Copyrights}

Copyright for this article is retained by the author(s), with first publication rights granted to the journal.

This is an open-access article distributed under the terms and conditions of the Creative Commons Attribution license (http://creativecommons.org/licenses/by/4.0/). 